\title{
Alumni Reflect on Their Education About Ethical and Societal Issues
}

\section{Dr. Angela R. Bielefeldt, University of Colorado Boulder}

Angela Bielefeldt is a professor at the University of Colorado Boulder in the Department of Civil, Environmental, and Architectural Engineering (CEAE) and Director for the Engineering Plus program. She has served as the Associate Chair for Undergraduate Education in the CEAE Department, as well as the ABET assessment coordinator. Professor Bielefeldt was also the faculty director of the Sustainable By Design Residential Academic Program, a living-learning community where students learned about and practice sustainability. Bielefeldt is also a licensed P.E. Professor Bielefeldt's research interests in engineering education include service-learning, sustainable engineering, social responsibility, ethics, and diversity.

Jake Walker Lewis,

Graduate of the University of Colorado Boulder with a bachelor's degree in environmental engineering and a master's degree in civil engineering. Was involved with undergraduate research regarding ethics in engineering education, presented work in the form of a poster at the 2018 Zone IV ASEE Conference. Defended and published master's thesis examining if/how ethics are being introducted in K12 STEM education in November 2019. Co-authored paper entitled "Educating Civil Engineering Students about Ethics and Societal Impacts via Cocurricular Activities." This paper was recognized by the Journal of Professional Issues in Engineering Education and Practice as an Editor's Choice. Currently working with Dr. Angela Bielefeldt as a research assistant. Preparing to submit three papers regarding ethics in engineering education as co-author at the 2020 ASEE Annual Conference \& Exposition.

\section{Dr. Madeline Polmear, University of Florida}

Madeline Polmear is a postdoctoral researcher in the Department of Civil and Coastal Engineering at the University of Florida. She completed her B.S. in environmental engineering, M.S. in civil engineering, and $\mathrm{Ph} . \mathrm{D}$. in civil engineering at the University of Colorado Boulder. Her research focuses on bridging technical and nontechnical competencies to support the professional preparation and ethical responsibility of engineering students.

\section{Dr. Daniel Knight, University of Colorado Boulder}

Daniel W. Knight is the Program Assessment and Research Associate at Design Center (DC) Colorado in CU's Department of Mechanical Engineering at the College of Engineering and Applied Science. He holds a B.A. in psychology from Louisiana State University, an M.S. degree in industrial/organizational psychology and a Ph.D. degree in education, both from the University of Tennessee. Dr. Knight's research interests are in the areas of $\mathrm{K}-12$, program evaluation and teamwork practices in engineering education. His current duties include assessment, team development, outreach and education research for DC Colorado's hands-on initiatives.

\section{Dr. Chris Swan, Tufts University}

Chris Swan is Dean of Undergraduate Education for the School of Engineering and an associate professor in the Civil and Environmental Engineering department at Tufts University. He has additional appointments in the Jonathan M. Tisch College of Civic Life and the Center for Engineering Education and Outreach at Tufts. His current engineering education research interests focus on community engagement, service-based projects and examining whether an entrepreneurial mindset can be used to further engineering education innovations. He also does research on the development of sustainable materials management (SMM) strategies. 


\title{
Alumni Reflect on their Education about Ethical and Societal Issues
}

\begin{abstract}
This study explored the extent to which engineering alumni felt that they had received adequate education to face ethical and societal issues in their work, and what they believed to be most helpful regarding their formal education on these topics. Mixed-methods were used to answer these research questions, using a survey instrument with responses from eight groups of alumni who had taken at least one course with exemplary integration of engineering ethics and one 'control' group, plus interviews with 14 engineering alumni. Among engineering alumni who had received at least one exemplary ethics educational experience, $58 \%$ rated the level that they believed they were adequately prepared through their education to face ethical issues in their work at 8-10 (on a scale of 1 to 10 ), and $49 \%$ rated their preparation to consider societal issues at $8-10$; only $1 \%$ and $4 \%$ rated these at 4 or less, respectively. These averages differed across institutions (e.g., average for ethical issues 8.2 at a religiously-affiliated R2 institution versus 6.3 at a Public R2 institution). Alumni described courses in college (undergraduate or graduate), if any, that impacted their understanding of the role of engineering and/or computing in society. These courses included an array of humanities/social science (HSS) courses and engineering courses (e.g., capstone design). Many described feeling somewhat unprepared for a variety of ethical situations on the job. Most advocated for greater engineering ethics education, primarily through integration into existing engineering courses. Limitations in the work include a fairly small sample. The results provide insights into how educational practices are influential in terms of the knowledge, attitudes, and behaviors of working engineers with respect to ethics and broader impacts.
\end{abstract}

\section{Background}

There are numerous incidents of unethical practices in engineering $[1,2,3]$ and times when negative impacts to communities and individuals have resulted from engineering projects $[4,5]$. It is clear that what is needed in practice is ethical behavior, and that regulations to police engineers' ethical behavior via professional licensure are not sufficient [6]. The first national exam required on the path to become a licensed professional engineer (PE), the NCEES Fundamentals of Engineering Exam (FE), includes questions that relate to ethics [7]. Prior to becoming a PE, some states also require exams to test ethics (e.g., [8]) and thirteen states require continuing education in ethics and/or professional practices to maintain PE license [9] ${ }^{1}$. However, one cannot assume that ethics knowledge will translate into ethical behavior, nor is either the FE or PE encouraged across all engineering disciplines. In addition, ethical behavior with respect to microethics is insufficient to address broader societal and environmental issues (which are typically considered macroethics) [10]. Engineering has increasingly recognized the links between ethics and the broader impacts of engineering, perhaps best exemplified by the change in the ABET Engineering Accreditation Commission student outcomes criteria [11] from two separate criterion -- (f) "an understanding of professional and ethical responsibility" and (h) "...understand the impact of engineering solutions in a global, economic, environmental, and societal context" -- to the single combined criterion (5) "An ability to recognize ethical and professional responsibilities in engineering situations and make informed judgments, which must

\footnotetext{
${ }^{1} 13$ states require continuing education devoted to ethics / professional responsibility: Delaware, Florida, Indiana, Iowa, Louisiana, Maryland, Minnesota, Mississippi, New Jersey, New York, New Mexico, Texas, Wisconsin
} 
consider the impact of engineering solutions in global, economic, environmental, and societal contexts."

The process by which individuals take a reasoned approach to making ethical engineering decisions have been described via a variety of frameworks including reflexive principlism [12] and a pragmatic approach [13]. In a widely applied model, the multistep process of ethical reasoning begins with the step of identifying an ethical dilemma, continues through information gathering, analysis, and perspective, before coming to a conclusion on an ethical course of action [14]. However, despite understanding an appropriate course of action, individuals may still behave unethically. Explorations of unethical behavior have explored this process using the Theory of Planned Behavior [15, 16] and identifying obstacles to ethical behaviors [17]. In a study on temptations to engage in unethical behavior in academic settings and work settings (e.g., undergraduates with internship experiences), similar decision-making processes and motivators were identified in the academic and work settings, although with differential importance in their model [18]. For example, engaging in cheating behavior in high school was predictive of decisions to violate workplace policies, indicating that individuals create behavior patterns or have consistent justifications and logic. The most significant types of pressures to violate workplace policies included peer behavior, wanting to seem better that they are, and someone telling them to do it. On the opposite side, conditions that caused them to hesitate to violate workplace policies included negative consequences, fear of getting caught, and it would require more work or money later.

Incidents of less-than-exemplary behaviors of engineers may lead us to question the adequacy of the educational preparation of engineers during college. A majority of engineering faculty believed that the ethics and/or societal impacts education of undergraduate and graduate students in their program was not sufficient [19]. This reflects differences in the extent that the formal curriculum integrates ethical and societal issues (e.g., some programs require a full course on engineering ethics, others have an ethics-across-the curriculum approach, others only include a single small ethics integration in capstone design) [20, 21]. In addition, some educators believe that ethics education should be grounded in theory versus others taking a more 'practical' approach [20]. There are also important differences among engineering disciplines. For example, the extent that macroethical issues such as sustainability are taught varies by discipline and varies within the professional codes across different disciplines [22].

Given the interdisciplinary nature of engineering work, overly narrow ethics education may hinder preparation for the true complexity of engineering practice. Stevens et al. [23] characterized engineering work as "heterogeneous" including social issues that are "almost inextricably tied" together with technical issues. Examples were provided that hearken to macroethical issues such as a "problematic environmental impact statement" and diverse stakeholders. They stated that "engineering education is currently tilted toward an image of success in engineering that emphasizes technical rationality... and participation in the corporate profit-making enterprise" and contrasts that with desires among engineering students to enter a profession that is "a force for social good." Thus, a misfit between engineering ethics education and engineering practice can often be seen as problematic.

In addition to questioning the adequacy of engineering education, there is also evidence that 
professional engineering morality and ethical commitment may regress over time in the workforce [24, 25]. However, studies of ethics in engineering practice are fairly limited. The following paragraphs profile three such studies. While not exhaustive, these studies provide some useful insights.

Nathans-Kelly et al. [26] conducted a survey of engineering alumni working in the engineering profession from a single institution $(n=162)$, interviews with 91 engineers / former engineers, and case studies within six engineering organizations. Two important themes were profit/time versus perfection ("reconciling the creation of a product in a safe and thorough manner while working under budget/profit demands within an organization") and ethics unseen (arguing that engineers did not perceive that daily decision making often had ethical implications). They distinguished between professional ethics, organizational ethics, and personal ethics, as well as explored differences between general professional ethical behaviors (e.g., honesty, quality, competency) and standards of professional practice (e.g., protect public health, safety, and welfare, protecting environment, relationship with employer). Among survey respondents, 52\% rated "maintaining professional ethical standards" as essential but based on the open-ended responses that followed concluded "incidents of applied ethics on the job are considered to be few and far between." In summarizing their interviews with practicing engineers, the authors conclude, "overwhelmingly, engineers responded to queries about ethics with a denial that they had even been part of or witnessed anything that challenged personal or organizational ethics... [but] practicing engineers have a powerful ethical compass that steers them in their daily pursuits."

In a study focused on engineering social responsibility, Bielefeldt and Canney [27] reported the results of survey responses from 504 engineers/alumni describing 719 different jobs. The most common response was that ethical/moral dilemmas were encountered infrequently and were not of significant personal concern (34\% of jobs); the second most common response was that they had never been confronted with an ethical or moral dilemma regarding how their work impacted people, society, and/or the environment. It seems unlikely that there were no ethical dimensions to their work, but rather individuals were unaware of these issues, similar to the ethics unseen theme in [26]. This points to the importance of the first step in the ethical decision making process of recognizing an ethical dilemma [14]. In academic courses, this step is often trivialized since students are told to conduct an ethical analysis of a case study. An alternative explanation as to why the survey respondents indicated that they had never been confronted with an ethical dilemma is that some may have been reluctant to share information that could potentially incriminate themselves or their employer, despite the anonymity of the survey.

Nudelman [28] explored the ethical situations that engineering students encountered during 'vacation work' (mini-internships of 4 to 6 weeks that were required for all engineering students at the University of Cape Town). The information was derived from 54 students who completed a homework assignment describing ethical dilemmas that they had encountered (another 83 completed the assignment but did not consent for their assignment to be included in the research study). Among the findings were 20 students who described observing unethical acts during their internship experience; the three types of these acts were data falsification, potential health risks, and workplace misconduct. There were 17 other students who described being coerced into participating in unethical acts by colleagues and/or supervisors. Finally, 17 students described a 
dilemma they self-identified and in which they exercised personal agency "related to intellectual property, company time and resource wastage, and tensions between the personal and professional." These ethical dilemmas are perhaps typical for entry-level engineers, and therefore are worthy of in-class discussion.

There is little data in the literature that provides evidence of the fit between engineering practice and the educational training that students received on engineering ethics, although some have postulated a misfit [29]. However, it is important to note that a variety of settings may impact students' ethical awareness and reasoning, including formal courses, extracurricular experiences, and the broader culture in higher education [30]. Wiedman's input-environment-output model of student socialization includes influences at multiple levels and predicts differences in educational experience among institutions and majors [31]. In addition, the NAE [32] reports that $65 \%$ of all individuals with degrees in engineering work in 'occupations not considered engineering' and $18 \%$ of those working in engineering occupations do not possess an engineering degree. Thus, non-traditional pathways are worth exploring.

Overall, engineering educators should strive to build a strong foundation in college to support the ethical behavior of its graduates in practice. But this is a difficult task without clear guidance. Engineering educators may base their ethics instruction on their own experiences as a student, experiences as a working professional, ideas from the literature or professional development training, and/or what is received well by students [33]. However, there is perhaps typically a lack of a process for closing the loop, by which alumni give feedback to faculty that could inform improvements. This investigation sought to use this approach to glean the opinions of working professionals on their ethics educational experiences.

\section{Research Questions}

The following research questions were explored in this study. It should be noted that ethics education references formal courses or learning that graduates experienced during pursuit of their degree.

RQ1. To what extent do engineering alumni feel that they received adequate education to face ethical and societal issues in their work? Does this vary among alumni from different institutions?

RQ2. What courses do alumni believe were helpful in their formal education to prepare them to face ethical and societal issues in their work?

RQ3. Do alumni believe that a specific 'exemplary course' that included engineering ethics was helpful in their work?

RQ4. In what ways do alumni describe their ethics and societal issues education in their courses as helpful in their work?

\section{Methods}

A mixed-methods approach was used in this study, including quantitative data from an alumni survey and qualitative data from the survey and interviews. The research was embedded within a 
larger project examining the macroethics education of engineering students. The research methods were reviewed by an Institutional Review Board for human subjects research and deemed exempt due to minimal risk level (Protocol \# 15-0326).

Survey Instrument. An alumni survey was developed through a multi-step process. Based on literature and the earlier phases of the project that included faculty surveys and interviews, a draft survey was developed. A convenience sample of alumni from three institutions was invited to take the draft survey and 12 responses were obtained in November and December 2017. The draft survey included a final open-ended question that invited feedback on the survey itself. Some respondents also emailed their opinions to the study PIs. The survey instrument was revised based on the feedback, largely becoming shorter. (Given the timing of the study, the older ABET criteria were in-force whereby ethics and societal/environmental impacts were framed as separate learning outcomes; therefore this type of language was used in the survey items given the assumption that alumni educated under the older paradigm may have a somewhat limited definition of engineering ethics.)

The final survey instrument is included in the Appendix. It included Likert, multi-select, and open-ended responses. The survey began with questions on a specific 'exemplary' course(s); i.e., one that explicitly embedded content on engineering ethics. For example, "Was learning about ethics and/or societal impacts in this course helpful to you in your work? If so, please explain." The survey then asked about the importance of ethics/societal issues in engineering/computing work, courses and co-curricular activities in college that impacted their ethical reasoning, and rating the level to which they felt adequately prepared to face ethical issues in their work ( 1 to 10 scale). The survey concluded with the frequency they had encountered various ethical issues in their work and demographic items (e.g., year they took exemplar course, year graduated with BS degree, undergraduate major, graduate education, types of engineering jobs). In addition, a slightly modified instrument was sent to alumni to represent a control group, which was a convenience sample from a large public institution. The survey was administered through Qualtrics.

Survey Population. Within the larger study, courses that integrated ethics and societal impacts education were examined as potentially exemplary practices [34]. Faculty teaching these courses agreed to email an invitation to the survey to alumni from their course. Table 1 provides a summary of the eight exemplary settings from which alumni survey responses were received, which included required courses $(\# 2,3,4,5)$ and elective courses (\#1) for engineering students. Setting 6 included multiple courses from the same institution, which were technical electives for engineering and other students (largely majoring in natural sciences). Settings 7 and 8 were more general elective courses for all students, which included engineering and non-engineering majors. Instructors of settings 1 to 8 emailed an invitation to the alumni survey in spring 2018; settings 1, 2, and 6 sent an additional invitation to recent graduates in fall 2019. Each survey respondent who provided their email address at the end of the survey was given a $\$ 10$ egift card to Amazon as compensation for their time. The number of individuals invited to participate in the survey was not reported by the partners (due in part to uncertainty with the validity of postgraduation email addresses). 
Table 1. Summary of alumni data sources

\begin{tabular}{|c|c|c|c|c|c|c|c|}
\hline \multirow[t]{2}{*}{$\#$} & \multirow[t]{2}{*}{ Institution } & \multirow[t]{2}{*}{ Course } & \multicolumn{2}{|c|}{$\begin{array}{c}\text { Survey } \\
\text { respondents, } \mathrm{n}\end{array}$} & \multicolumn{2}{|c|}{$\begin{array}{c}\text { Volunteered for } \\
\text { interview, } \mathrm{n} \\
\end{array}$} & \multirow[t]{2}{*}{$\begin{array}{c}\text { Interview } \\
\text { Pseudonyms }\end{array}$} \\
\hline & & & engineers & other & engineers & other & \\
\hline 1 & Relig-R2 & Engrg Ethics elective & 58 & 0 & 15 & 0 & $\begin{array}{l}\text { Calvin, Gene, } \\
\text { Howard, Larry }\end{array}$ \\
\hline 2 & Relig-M & Prof/Ethics req'd & 24 & 0 & 6 & 0 & William \\
\hline 3 & Relig-Bac & First-year eng req'd & 19 & 0 & 4 & 0 & Owen, Sophie \\
\hline 4 & Public-M & Professional Issues & 3 & 0 & 1 & 0 & - \\
\hline 5 & Private-M & Professional Issues & 1 & 0 & 0 & 0 & - \\
\hline 6 & Pubic-R1 & $\begin{array}{l}\text { ChemEng sustainable } \\
\text { energy courses }\end{array}$ & 20 & 16 & 3 & 0 & - \\
\hline 7 & Public-R2 & Communications & 10 & 4 & 1 & 1 & Roland \\
\hline \multirow[t]{2}{*}{8} & Public-R1 & Ethics & 5 & 12 & 1 & 2 & - \\
\hline & TOTAL & & 140 & 32 & 31 & 3 & 8 \\
\hline $\mathrm{X}$ & LPU-R1 & $\begin{array}{l}\text { (no specific to serve } \\
\text { as control) }\end{array}$ & 8 & 0 & 7 & 0 & $\begin{array}{c}\text { Anne, Brad, Denise, } \\
\text { Kathy, Melissa, } \\
\text { Shane }\end{array}$ \\
\hline & TOTAL & & & & & & 14 \\
\hline
\end{tabular}

Based on the demographic responses, the majority of the alumni from settings \#1, \#2, and \#3 majored in mechanical engineering, followed by electrical and/or computer engineering, and biomedical engineering. Setting \#6 was primarily chemical engineers, and the control setting was primarily civil/environmental engineers. Other alumni majors included materials, petroleum, industrial, and aerospace engineering. Note that among the 140 individuals with engineering degrees who participated in the exemplary ethics education settings, 30 had never worked as an engineer or computer scientist after graduating from college and 6 more were not currently working as an engineer or computer scientist but previously had. These numbers are not surprising given the NAE pathways data [32]. Among those with engineering degrees in settings $\# 2-\# 8$, the median time since graduating with their Bachelor's degree was 1 year. For setting \#1 the median time since graduation with a Bachelor's degree was 4 years, with a range of 0.5 years to 13 years. In the control setting the median time since their Bachelor's degree was 8 years (range 2 to 12 years). Although none of the individuals without engineering degrees indicated that they were working as an engineer or computer scientist, most were majors that would commonly work alongside engineers (e.g., biomedical science, biology, biochemistry, environmental science, geophysics, and business). This was acknowledged by some respondents; e.g., "I am learning more and more about how cities are planned, how they function, and how people interact with their communities. Good engineering and design can greatly benefit cities and their citizens." While the responses from these non-engineers are not analyzed in detail, keeping these individuals in mind is important because they may be co-workers with engineers whose behavior contributes to the overall corporate culture in which engineers work.

Other demographics reported by the survey respondents included:

Gender: male (61.2\%), female $(37.1 \%)$, other $(0.6 \%)$, prefer not to say $(1.2 \%)$

Race/ethnicity ( 5 individuals selected two categories, thus the total percentage exceeds 100\%): White non-Hispanic (81.8\%), Hispanic/Latino (8.2\%), Asian (5.9\%), African American / Black (2.4\%), other (1.2\%), prefer not to say (3.5\%), American Indian and/or Alaska Native (0\%), Native Hawaiian ( $0 \%)$

Grew up primarily in the USA: yes $(93.5 \%)$, no $(6.5 \%)$ 
Note that some individuals skipped one of more of the demographic survey items.

Data Analysis. For statistical analysis of the Likert-type responses, t-tests were conducted in Excel; these tests are generally robust to non-normality and Likert-type data [35-37]. Nonparametric tests were conducted in SPSS. This included paired tests to compare ethical versus societal preparation and Kruskal-Wallis and Mann-Whitney U tests to compare the responses among different institutions.

Themes from the open-ended responses describing how the exemplar course was helpful in their work were analyzed by two researchers. The second author read all of the responses and developed a code book using themes that emerged from the data. He applied these codes to the responses, then discussed and modified a few of the codes, and reapplied the codes to all of the responses. At this point the first author applied the codes to the responses, noted questions about the definitions of the codes, and computed interrater reliability using Cohen's Kappa. This led to a discussion of the code definitions between the authors, clarifications added, and the first author recoding the responses and recomputing Cohen's Kappa. Other coded survey responses were also discussed among the two coders.

Interviews. In addition to the survey data, semi-structured interviews were conducted. The key interview questions pertinent to the current study are:

- Would you tell me about the ways that you believe your college education was effective in preparing you to face ethical and societal issues through the course of your work?

- How do you think engineering education could be improved to help better prepare students for the ethical and societal issues that they will face in their work?

A question on the survey asked individuals to provide their email contact information "if you would be willing to participate in an interview about how the instruction you received on ethics/societal impact as a student impacted you after graduation". The number of volunteers is summarized in Table 1. About 15 were invited to participate in interviews in fall 2019, with a second round of invitations (to all of the engineering majors including the non-respondents from round 1) in fall 2020. Due to the low number of interviews, 6 alumni from the control institution were also interviewed. In all, interviews were conducted with 14 engineering alumni. Those participating in an interview were compensated for their time with a \$50 egift card to Amazon. Demographic information on the interview participants is reported in Table 7 and [38].

Interviews were conducted over the phone or via skype by the second author. The interviews were audio recorded, and a transcript made, assisted using the online transcription software Trint. Pseudonyms were randomly assigned. The open-ended responses from the interviews were coded using deductive methods by the two lead authors. A negotiated process was used to come to agreement on the themes from the interview responses.

\section{Results and Discussion}

\section{RQ1. Level of preparation}

The survey included the question "To what level do you believe you were adequately prepared 
through your education to: (1) face ethical issues in your work, and (2) consider societal issues in your work?" The response scale ranged from 1 (not at all) to 10 (fully prepared). Results are summarized in Table 2. The majority of the 172 responses from individuals who had received at least one 'exemplary' ethics educational experience were high, with $58 \%$ rating their preparation for ethical issues at 8-10 and 52\% rating preparation to consider societal issues at 8-10; only 2\% and $5 \%$ rated these at 4 or less, respectively. These results among all alumni were similar to the results from individuals who majored in engineering. In paired tests among the engineering students, ratings for ethical issues differed from societal issues (paired 2-tailed t-test $\mathrm{p}=.005$ ); however, the ethical and societal issues ratings were strongly correlated (Pearson correlation 0.66). At the two religiously-affiliated institutions, the average preparation ratings for ethics were higher than for societal issues; at the other institutions the differences were not statistically significant. In contrast, at the public institutions the average preparation ratings for societal issues were higher than for ethical issues, although the differences were not statistically significant (note that the lower number of survey respondents causes lower statistical power).

Table 2. Level alumni felt adequately prepared for these issues in their work

\begin{tabular}{|l|ccc|ccc|}
\hline Group / institution & \multicolumn{3}{|c|}{ Ethical Issues } & \multicolumn{3}{c|}{ Societal Issues } \\
(number of responses) & Avg (stdev) & $\% 8-10$ & $\% \leqq 4$ & Avg (stdev) & $\% 8-10$ & $\% \leqq 4$ \\
\hline All at 8 exemplars (n=172) & $7.8(1.5)$ & 58 & 2 & $7.5(1.6)^{\mathrm{A}}$ & 52 & 5 \\
Eng at 8 exemplars (n=140) & $7.8(1.5)$ & 58 & 1 & $7.5(1.6)^{\mathrm{A}}$ & 49 & 4 \\
1 Eng Relig-R2 (n=58) & $8.2(1.3)$ & 66 & 0 & $7.8(1.5)^{\mathrm{A}}$ & 60 & 3 \\
2 Eng Relig-M (n=24) & $8.4(1.0)$ & 83 & 0 & $7.5(1.2)^{\mathrm{A}}$ & 50 & 4 \\
3 Eng Relig-Bac (n=19) & $7.4^{1,2}(1.4)$ & 37 & 0 & $7.2(1.5)$ & 37 & 5 \\
6 Eng Public R1 (n=20) & $6.9^{1,2}(1.7)$ & 30 & 0 & $7.2(1.7)$ & 35 & 5 \\
7 Eng Public R2 (n=10) & $6.3^{1}(1.9)$ & 30 & 10 & $6.7^{1}(1.7)$ & 30 & 10 \\
Eng LPU R1 Control (n=12 $)$ & $6.3^{1}(1.8)$ & 17 & 17 & $6.8^{1}(1.7)$ & 50 & 8 \\
\hline
\end{tabular}

$\sim 7$ responses from 2020 and 5 from pilot phase; ${ }^{1}$ statistically significant difference $(p<.05)$ compared to Setting \#1

2 statistically significant difference $(\mathrm{p}<.05)$ compared to Setting \#2

A statistically significant difference $(\mathrm{p}<.05)$ in paired t-test versus ethical issues rating

The average alumni ratings for ethical preparation did differ across institutions (e.g., average highest at the Religiously-affiliated R2 and Religiously-affiliated Masters institutions). The highest percentage of alumni from the control institution as compared to the other institutions rated their ethical preparation at 4 or lower, which is not unexpected given that the other alumni experienced at least one course that integrated ethics education in an exemplary manner. However, another differentiating factor is the longer time in practice among the survey respondents from the control institution compared to the other 7 institutions. The types of ethical issues encountered likely vary with time in practice and could be a factor, in addition to recent improvements in ethics education in engineering. There were a low number of alumni responses from the majority of the institutions which poses a limitation to the study.

\section{RQ2. Courses alumni identified as impactful}

Alumni were asked which courses in college (undergraduate or graduate), if any, impacted their ethical knowledge, reasoning, or behavior, and the understanding of the role of engineering and/or computing in society. The courses listed were clustered into groups (see Table 3), with the percentage of the engineering alumni who discussed a particular course type summarized in Table 4. Beyond the 'exemplar' courses, some specific courses were particularly common among 
the respondents at particular institutions, which have been identified in Table 3.

Table 3. Course types listed among the survey responses (specific to an institution)

\begin{tabular}{|c|c|c|}
\hline Course type & $\begin{array}{l}\text { Examples listed among courses contributing to } \\
\text { ethics }\end{array}$ & $\begin{array}{l}\text { Examples listed among contributing } \\
\text { to understanding role in society^ }\end{array}$ \\
\hline $\begin{array}{l}\text { Ethics } \\
\text { (Eth) }\end{array}$ & $\begin{array}{l}\text { Engineering Ethics, 1-cr graduate course, } \\
\text { Environmental Ethics, bioethics, ethics in medicine, } \\
\text { Christian Ethics, Ethics \& Professionalism, } \\
\text { Engineering Ethics (I2) }\end{array}$ & \\
\hline $\begin{array}{l}\text { Humanities or } \\
\text { social science } \\
\text { (HSS) }\end{array}$ & $\begin{array}{l}\text { Great Texts (I1), Science and Values (I3), } \\
\text { philosophy, sociology, social psychology, Christian } \\
\text { history, religion, Nature and Human Values (I7), }\end{array}$ & Technical writing / communication, \\
\hline $\begin{array}{l}\text { First-year } \\
\text { engineering (FY) }\end{array}$ & Introduction to Engineering, First-Year Design & \\
\hline $\begin{array}{l}\text { Engineering } \\
\text { (Eng) }\end{array}$ & $\begin{array}{l}\text { statics, dynamics, Advanced Polymers, Materials, } \\
\text { junior design course, machine design, aircraft } \\
\text { structures, engineering economics, renewable } \\
\text { energy }\end{array}$ & $\begin{array}{l}\text { Humanitarian service-learning } \\
\text { course, mech eng lab, bioinformatics, } \\
\text { CAD, embedded systems, medical } \\
\text { devices, fluid dynamics... }\end{array}$ \\
\hline $\begin{array}{l}\text { Capstone eng } \\
\text { design (CDsn) }\end{array}$ & Senior design & \\
\hline Other & $\begin{array}{l}\text { leadership, entrepreneurship, business, project } \\
\text { management, seminar (I3), professional issues (I5) }\end{array}$ & Coaching for engineers \\
\hline
\end{tabular}

For courses that impacted ethical development, about half of all alumni identified a course with ethics in the title. This included three of the exemplar courses (at I1, I2, and I8). Some students listed multiple ethics courses. HSS courses were listed by about a third of the alumni as impacting ethical development, with course titles commonly including religious themes (at I1, I2, and I3) and some students noting these courses were associated with a minor (such as philosophy); this also included the exemplar course at I7. Ethics and HSS courses were less frequently listed among the courses contributing to understanding the role of engineering and/or computing in society. First-year engineering courses contributed to understanding ethics and role in society for about $14-18 \%$ of the engineering alumni. Engineering capstone design was listed as contributing to understanding their role in society for about a third of engineering alumni (more than 18\% for ethics) and about half of the alumni listed one or more different engineering courses (more than $28 \%$ for ethics). The course types commonly listed appeared to differ among institutions (although given the low number of survey respondents, these data were not tested statistically).

Table 4. Percentage of engineering alumni discussing different course types in their open-ended responses (bold indicates some responses were the exemplar course)

\begin{tabular}{|l|ccccc|ccccc|}
\hline $\begin{array}{l}\text { Group and institution } \\
\text { (number of write-in responses) }\end{array}$ & \multicolumn{6}{|c|}{ Ethics knowledge, reasoning, behavior } & \multicolumn{5}{|c|}{ Role of engineers/CS in society } \\
\hline & Eth & HSS & FY & Eng & CDsn & Eth & HSS & FY & Eng & CDsn \\
\cline { 2 - 11 } Eng at 8 exemplars (126, 114) & 56 & 37 & 14 & 28 & 18 & 32 & 13 & 18 & 47 & 33 \\
1 Eng Relig-R2 (53, 49) & $\mathbf{8 3}$ & 26 & 6 & 25 & 9 & $\mathbf{6 1}$ & 8 & 20 & 47 & 29 \\
2 Eng Relig-M (20,17) & $\mathbf{7 5}$ & 50 & 5 & 10 & 20 & $\mathbf{2 9}$ & 0 & 12 & 18 & 47 \\
3 Eng Relig-Bac (17,13) & 0 & 47 & $\mathbf{5 9}$ & 35 & 29 & 0 & 54 & $\mathbf{3 1}$ & 77 & 46 \\
6 Eng Public R1 (18,16) & 6 & 33 & 11 & $\mathbf{7 2}$ & 50 & 0 & 0 & 6 & $\mathbf{8 1}$ & 56 \\
7 Eng Public R2 (9,10) & 33 & $\mathbf{6 7}$ & 11 & 11 & 0 & 0 & $\mathbf{4 0}$ & 20 & 40 & 10 \\
\hline
\end{tabular}


Some students explicitly wrote in none ( $\mathrm{n}=3$ for ethics, $\mathrm{n}=9$ for role in society). Some alumni indicated all or most of their engineering courses ( $n=3$ for ethics, $n=13$ for role in society) or all of their college courses ( $n=2$ for ethics, $n=5$ for society; e.g., "I feel like all of my courses did as well to a certain extent"). Some students explicitly noted that the answers to the ethics and role of engineering/computing in society questions were the same or listed the same courses (12 alumni at I1, 2 at I3, 4 at I6), which indicates that some individuals strongly connected the ideas of ethics and role in society in alignment with macroethics.

It was of interest to see if the number of different courses listed differed for contributing to ethical development versus the role of engineers in society, or across different institutions. Responses that noted all engineering courses were assigned 10, all college courses assigned 15, and otherwise the number of different courses listed was counted. Overall, among the engineering alumni who answered the question, an average of 2.4 courses for ethics were written in and 3.3 courses for role in society. The number of courses contributing to ethical development was the highest at institution 3 (average 3.2 at the religiously-affiliated Bachelor's institution). The average number of courses listed as contributing to the understanding of the role of engineering or computing in society was also the highest at institution 3 (average 5.2). Note that alumni responses from institution \#7 had the highest variability, with three students saying none and another saying all core classes and first year engineering design.

In the future, if an expanded survey-based quantitative study was planned, it might be worth directly asking about the types of courses that discussed engineering ethics and/or societal role and asking about the total number of courses the included these topics. Individuals taking surveys generally seem more inclined to answer questions where they can select a response versus typing in open responses. Alternatively, one may be able to collect pilot data from students, alumni, and/or faculty and then pre-populate the survey with specific courses. However, this type of question style could be more likely to engender acquiescence response bias, whereby individuals agree that the courses contributed without careful consideration. Thus, a survey that included that question style may want to also intentionally list some courses generally believed to not include ethics or societal issues to serve as a negative control.

\section{RQ3. Whether exemplary course was helpful}

On the survey, alumni were asked, "Was learning about ethics and/or societal impacts in this course helpful to you in your work? If so, please explain." This question asked specifically about the exemplary course that they had enrolled in, from whose instructor they had received the survey invitation. The open-ended responses were coded into 3 categories: yes, somewhat, and no. The percentage of responses of each type from among the engineering alumni are summarized in Table 5 for institutions with 8 or more responses (note that the number of responses may differ from RQ1, since this was an open-ended question that appeared earlier in the survey). The responses categorized as yes included descriptors such as absolutely, definitely, and yes. The responses categorized as somewhat included descriptors such as partially or yes and no (e.g., "On a high level, yes. It is important to think about the ethical consequences of our work and companies. On a day to day basis, no."). There was some subjectivity around the responses that lacked a qualifier before providing examples. Based on the nature of the response, the first author coded many of these as 'somewhat' (when the statement seemed to provide limited examples) while the second author tended to use more binary coding of yes or no. The 
Cohen's Kappa for rater agreement was 0.72 . The more conservative values of the first author are presented in Table 5.

Table 5. Survey responses from engineering alumni related to whether learning about ethics and/or societal impacts in the exemplar course has been helpful in their work

\begin{tabular}{|lllc|ccc|c|}
\hline$\#$ & Institution & Course & N & $\begin{array}{c}\text { Yes, } \\
\%\end{array}$ & $\begin{array}{c}\text { Somewhat, } \\
\%\end{array}$ & $\begin{array}{c}\text { No, } \\
\%\end{array}$ & $\begin{array}{c}\text { Paired test } \\
\text { sig }<.1\end{array}$ \\
\hline & All & All - engineers & 130 & 68 & 26 & 6 & \\
1 & Relig-R2 & Engrg Ethics & 60 & 85 & 15 & 0 & 2 \\
2 & Relig-M & Professionalism+Ethics & 21 & 38 & 33 & 29 & $1,3,6$ \\
3 & Relig-Bac & First-year Engineering & 15 & 67 & 33 & 0 & 2 \\
6 & Pubic-R1 & ChemE sustainable energy course, 2x & 17 & 52 & 41 & 6 & 2 \\
7 & Public-R2 & Communication & 8 & 63 & 38 & 0 & \\
\hline
\end{tabular}

A non-parametric Kruskal-Wallis test was first conducted across the engineering alumni from all institutions; an institutional difference was found (asymptotic sig. 0.004). In the subsequent paired tests ratings among alumni from institution I2 differed from three other institutions (I1, I3, I6), presumably due to the low percentage of yes and high percentage of no responses. The reason that about a third of the alumni from setting \#2 did not perceive the course as helpful in their work is unclear. The alumni had nearly uniformly high ratings of feeling prepared through their education to face ethical issues in their work (average 8.4, Table 2), but perhaps this was due to other courses that they had taken rather than the senior-level engineering professionalism and ethics course. 12 required multiple ethics courses outside engineering that were taken earlier in their undergraduate careers, and perhaps those courses were viewed as being more helpful. In addition, the 12 course was new (in first to third iterations) and the alumni who responded to the survey had only worked for about 1 year after graduating. The short time in-practice was not atypical compared to alumni respondents from institutions I3, I6, and I7. The exemplar instructors from I1, I3, I6, I7 did appear to have more established courses. More information is needed to understand this difference; with more time in practice, alumni from $\mathrm{I} 2$ may have come to realize how the content in the course was helpful. Longitudinal data would be needed to explore this idea.

\section{RQ4. How ethics and/or societal impacts education helpful}

The open-ended survey responses were examined to characterize how engineering alumni explained their response as to whether learning about ethics and/or societal impacts in a particular exemplar course was helpful in their work. The responses clustered into 11 main themes, summarized in Table 6. Each alumni response was coded to a median of 1 theme; a maximum of 4 themes were identified in a single response. Most responses were not particularly long; the median response length was 27 words (average 34 words).

Some of the reasons that individuals considered their education helpful were consistent across the yes and somewhat categories. For example, a number of individuals referred to the "foundation" from the courses as important. Others discussed their instruction as helpful in the first stage of identifying an ethical dilemma. 
Table 6. Themes in the alumni survey descriptions of how the exemplar course was helpful

\begin{tabular}{|c|c|c|c|c|}
\hline Theme & Definition & Example Quote & $\mathrm{n}$ & IRR \\
\hline Foundation & $\begin{array}{l}\text { A personal ethical foundation, professional } \\
\text { ethical foundation, viewpoint, thinking, or } \\
\text { conduct that was developed from their } \\
\text { academics. }\end{array}$ & $\begin{array}{l}\text { it gave me a foundation for ethical } \\
\text { conduct in a technical and professional } \\
\text { environment. And having that } \\
\text { foundation made it easier to develop the } \\
\text { reflex to assess every decision from an } \\
\text { ethical standpoint. }\end{array}$ & 51 & .86 \\
\hline $\begin{array}{l}\text { Identify } \\
\text { dilemmas }\end{array}$ & $\begin{array}{l}\text { Response indicates an ability to identify, } \\
\text { assess, detect, process or discern an ethical } \\
\text { issue or concept. May demonstrate an } \\
\text { awareness of ethical issues by identifying } \\
\text { some situations as unethical. }\end{array}$ & $\begin{array}{l}\text {...easier to detect when an ethical issue } \\
\text { is occurring. }\end{array}$ & 35 & .84 \\
\hline Impacts & $\begin{array}{l}\text { Insight or awareness into how their work or } \\
\text { engineering work they are aware of is } \\
\text { impacting society, their workplace, or other } \\
\text { external environments }\end{array}$ & $\begin{array}{l}\text { Mostly in helping me be conscientious } \\
\text { of how decisions I make, as well as } \\
\text { decisions made by my peers and } \\
\text { supervisors, can impact others both } \\
\text { inside and outside the company. }\end{array}$ & 36 & .90 \\
\hline Safety & $\begin{array}{l}\text { Importance and/or concern for the safety, } \\
\text { health, and/or wellbeing of people }\end{array}$ & $\begin{array}{l}\text { It was important for me to be affirmed } \\
\text { that time- and budget-based restraints do } \\
\text { not hold precedence over the due } \\
\text { diligence required towards the safety of } \\
\text { life and property. }\end{array}$ & 14 & .96 \\
\hline Competence & $\begin{array}{l}\text { Importance of conducting responsible, } \\
\text { informed, and/or professional work with } \\
\text { engineering }\end{array}$ & $\begin{array}{l}\text { while performing calculations, if I'm } \\
\text { uncertain I'll seek out senior help } \\
\text { instead of trying to figure it out on my } \\
\text { own. }\end{array}$ & 8 & .94 \\
\hline $\begin{array}{l}\text { Cultural } \\
\text { awareness }\end{array}$ & $\begin{array}{l}\text { Awareness of perspectives of other people, } \\
\text { stakeholders, and/or organizations } \\
\text { regarding their work. }\end{array}$ & $\begin{array}{l}\text {...now when I encounter something at } \\
\text { work, I know to step back and consider } \\
\text { all the details from the perspective of } \\
\text { every stakeholder. }\end{array}$ & 13 & .93 \\
\hline $\begin{array}{l}\text { Lifelong } \\
\text { learning }\end{array}$ & $\begin{array}{l}\text { Continuing education and/or continuing } \\
\text { development as a practicing engineer. }\end{array}$ & $\begin{array}{l}\text { My work requires an ethics training } \\
\text { course to be taken every year which is } \\
\text { used as a better real world example of } \\
\text { ethics }\end{array}$ & 3 & .96 \\
\hline Legal issues & $\begin{array}{l}\text { Legal issues such as product liability, } \\
\text { intellectual property, bribery. }\end{array}$ & $\begin{array}{l}\text { the applications of conflict of interest } \\
\text { and the ideas about why it is important } \\
\text { to be ethical in workplace do apply. As } \\
\text { a consultant, trade secrets are important }\end{array}$ & 5 & .97 \\
\hline Sustainability & $\begin{array}{l}\text { Importance of sustainability, sustainable } \\
\text { design, and/or how engineers are } \\
\text { responsible for the environment. }\end{array}$ & $\begin{array}{l}\text { It is very helpful when it comes to } \\
\text { business ethics, and especially } \\
\text { environmental/sustainable ethics. }\end{array}$ & 12 & .97 \\
\hline Achieve goal & $\begin{array}{l}\text { Learning ethics helped them achieve a } \\
\text { particular goal with academics or their } \\
\text { career (e.g. pass FE exam, useful in other } \\
\text { courses). }\end{array}$ & Helped me pass the FE exam. & 6 & .91 \\
\hline Motivation & $\begin{array}{l}\text { Learning ethics motivated them to seek out } \\
\text { an objective and/or career path, or believe } \\
\text { will be important later in their work or life. }\end{array}$ & $\begin{array}{l}\text { it made me want to pursue a role that } \\
\text { benefited humanity and work on } \\
\text { sustainable engineering practices. }\end{array}$ & 9 & .91 \\
\hline
\end{tabular}

IRR values in italics are based on the second round of coding

Some of the answers coded as 'somewhat' contrasted college education with on-the-job training or lifelong learning, and others described only limited helpfulness: 
In some respects, yes. It helped build categories and certainly made me think about diverse and complex moral issues with respect to engineering. But does knowing Kantian ethics make you a better man or a better neighbor? Does knowing that you need to stand your ground in the face of social pressures give you the strength to do so? In my experience, no. I think the ethics class is useful only to a Christian who might begin to see the enormous responsibilities engineers and scientists have been given to protect our world, but who will also be given the strength (over time) to stand their ground against a world who may not agree.

Nothing in particular sticks out, but the class at least made me aware that such issues exist. Because of that, I can remain more alert to ethical issues in the workplace.

Partially. As a product designer, I must ensure that my works is up to standards and codes. There have been situations that would lean towards skipping important certifications and testing, so having a strong foundation in ethics has kept me honest.

Other open-ended responses on the survey communicated perspectives on limitations of their engineering education. One biomedical engineer from I2 noted, "I was rarely exposed in my education to the end user of the designs I one day might make. The hardest part of BME is knowing what the needs are. I can day dream all day of unique designs but ultimately the goal is to enhance the quality or prolong the length of life. Knowing where that can be improved is vital."

\section{Interviews}

Richer descriptions of what about their educational experiences has been helpful on the job were provided in the interviews with alumni from the exemplar courses and the control institution (X). Basic information about the interviewees is summarized in Table 7.

Table 7. Characteristics of engineering alumni who participated in interviews

\begin{tabular}{|c|c|c|l|l|}
\hline Pseudonym & Setting & $\begin{array}{c}\text { Yrs since } \\
\text { graduation }\end{array}$ & \multicolumn{1}{|c|}{ Employment } & \multicolumn{1}{|c|}{ Notes } \\
\hline Gene & 1 & 7 & CAD Dsn; Process Engr & MBA; discussed institutional culture \\
Calvin & 1 & 1.5 & 2 internships, Aerosp. industry & Ethics course with cases, discussions \\
Howard & 1 & 0.5 & Industry (mech eng) & Discussed capstone design \\
Larry & 1 & 1.5 & Internship (electrical / patents) & In law school; discussed FY engrg course \\
\hline William & 2 & 1 & Consulting (mech/HVAC) & Philosophy courses impactful for ethics \\
\hline Sophie & 3 & 1 & 2 internships; Consulting eng & Project-based service-learning \\
Owen & 3 & 1 & 3 internships, Industry (elect) & Project-based service-learning \\
\hline Roland & 7 & 0.5 & 2 internships, Oil\&Gas Co. & HSS courses, capstone design \\
\hline Denise & $\mathrm{X}$ & 1 & 2 internships; Public utility & FY engrg course, env eng capstone design \\
Anne & $\mathrm{X}$ & 1 & 2 internships; Industry & FY engrg course, env eng capstone design \\
Kathy & $\mathrm{X}$ & 1.2 & 2 internships; Sust Consulting & Design courses thur curriculum in GenEng \\
Shane & $\mathrm{X}$ & 7 & Env Engrg consulting & BS/MS, PE, little recollection of ethics ed \\
Brad & $\mathrm{X}$ & 8 & 3 internships, 3 consultants & P.E. Environmental, currently MS student \\
Melissa & $\mathrm{X}$ & 20 & Env consulting, public sector & P.E., manager, not signif ethics ed \\
\hline
\end{tabular}

It is significant that so many alumni took the survey from Institution 1 . This perhaps implies that a number of the individuals remembered the professor and/or course fondly. This was confirmed 
by the interviews. Gene from I1 had worked at an engineering job that was mechanical designfocused right after college for about 1 year, earned an MBA, and then had been working in process engineering for about 5 years. He described routinely encountering ethical issues in his work, e.g., "I would say on a week by week basis, I'm always encountering someone who's lying or trying to give me a half truth or just trying to take the easy way without doing the job 100 percent." There was an overall sense that he felt prepared through his engineering education to cope despite

how widespread it is for people to just have no morals or ethical conscience at all. ... I was not prepared for the culture of unethical behavior. That's what I wasn't prepared for, to be a part of that constantly and always having to be trying to fight through to discern when people are telling the truth, when they're not. When people are making the right decision or the wrong decision versus just an honest mistake.

Gene described the overall institutional culture at I1 that emphasized academic honesty, with an emphasis on positive behaviors and sanctions for negative behaviors. He went on to discuss the exemplar engineering ethics course that he took, which had a strong focus on "case studies of the engineering ethical dilemmas in the real world that have actually happened." These included thinking about what you should do and why, but also "also just understanding the gravity of what it means to be an engineer, especially when you're designing things that have the potential to really change people's lives." Despite having taken the course about 9 years previous, Gene was able to recall specific cases from the course. And while he did not recall a lot of ethics integration in his other courses, within the full course he noted "I think the examples that they chose were just so powerful, it just kind of stuck with me." The overall culture at the institution reinforced the importance of ethics for engineers,

basically what it told me was that [ethics is] so important that the program decided it was worth a whole three hour credit requirement to cover the topic really well. ... I've definitely thought it was good to see that the university wanted that to be a priority.

This quote seems to relate to the notion of hidden curriculum and its potentially important role in education [39]. This interview confirmed the sense that his engineering ethics course / professor at I1 was exemplary, supported by the overall institutional culture.

Another alumnus from the same engineering ethics course from I1, Calvin, also described the course as effective in preparation for ethics in the workplace. Calvin had worked at two different engineering internships and had been working in his current position after graduating with his mechanical engineering degree for about 1.5 years. Calvin gave specific examples from the course and case studies that related to his current job, including conflict of interest, supplier interaction, and sustainability/ environmental impacts. He indicated that the group discussions in the course were particularly impactful. In discussing how and why he felt prepared to manage ethical considerations at this job he said:

It is a balance between knowing the way things are done, where you're going, and knowing how to navigate the situations. ... I think that the experience I had, especially in the [exemplar ethics] class of Professor [X] was pretty great for that kind of perspective, a well-rounded picture and also [including] case studies... There is nothing [in the real world] that goes by a textbook. So really looking at specific instances [of ethical issues] and how you might go about figuring out what the right thing to do, and what the things you can do, is the best way to go about it... I think the best you can do is get people up and get this thinking [started]. 
The engineering ethics course was clearly important in developing Calvin's mindset about the significance of ethical issues in the profession. He said,

before taking the course, I hadn't really thought about [ethics]. I definitely would say it's not something that came to mind when I thought of engineering.... And even leading up to the course, I didn't really think of it as something that would be that useful. I thought it was just something that would be kind of easy. It was a required course for us. Before that [course] I hadn't really thought about all the ways that.. all the ethical considerations there are in engineering and in business. ... But the class was eye opening and understanding why those things are important and how to deal with other businesses and other people in the workplace.

Based on his experiences in the work place Calvin said ethics were very important. Similar to Gene, Calvin also discussed the broader culture for ethics at his Christian university.

Howard had been working for about 6 months as a design engineer after graduating from I1 with his Bachelor's degree in mechanical engineering. Similar to both Gene and Calvin, Howard spoke confidently about being prepared through his education for job-related ethics. He initially focused his examples of ethics in the workplace primarily on ideas of competence and getting help to ensure that his work was of the highest quality. He discussed the role of capstone design in this preparation. When asked specifically about the engineering ethics course he discussed that the course made him think about both environmental and community impacts from engineering. Howard said the course was "absolutely" helpful, "I think that it's healthy for me to sit there and think, 'okay, what are the ethical concerns of my design' ... [and] think about the negative consequences. And I think that's something that I've taken away from that class."

The final alumnus from I1 interviewed was Larry, who went into law school after earning his B.S. in electrical engineering. Given this career path, his perspective was somewhat different. He had previously worked as an engineering intern and planned to work on electrical engineeringrelated patent litigation in the future. Larry started out by recalling how his very first engineering class impressed upon the students the importance of engineering work for human health and safety, "don't take for granted even the simple stuff, because... people could end up dying." He gave other examples of multiple engineering courses that reinforced the broader impacts of engineering, often through the stories of engineering faculty who had real world experience. "I think I was pretty well prepared ethically to understand that some of this stuff, even though it may seem mundane, is actually really important and doing it correctly could save the potential for a lot of harm." The engineering ethics course appeared to come near the end of his education, and he recalled various case studies that were discussed in the class and also said he liked the "more theoretical conversations" in the class. He believed that the practical examples integrated into courses was a good complement to the deeper immersion in the engineering ethics course.

Three alumni who attended the other two religiously-affiliated institutions in the study (one from I2 and two from I3) also felt well-prepared ethically. William from I2 discussed primarily nonengineering courses, feeling that "philosophical classes that also have theology integrated into them" were most impactful by providing a base for engineering ethics. William felt well prepared to "get a job that can help serve society." Owen and Sophie, graduates from I3, focused on project-based learning experiences, which in many cases were service-learning projects for real clients. Owen said, "every single semester you had some project like this which brought in 
ethical and societal impact issues." Both Owen and Sophie described this integrated approach to ethics in complex, authentic engineering projects. This is a contrast to the alumni from I1 and I2 who tended to describe entire ethics-focused courses as impactful. This shows that different models of ethics education can be perceived by alumni as appropriate for their later work as engineers.

The single alumnus interviewed from public institution I7, Roland, described a number of courses that integrated ethical issues, including humanities/social science courses, engineering courses, and capstone design. He said, "I think there was effort [to teach ethics] and I don't think it was lacking necessarily, but it's just hard to really do a lot of that stuff from a classroom." He described that much of this education focused on stakeholder engagement and cultural issues, including international settings, which had not been highly relevant to him in his work as a petroleum engineer. His work is more field-oriented, and he gave the example of environmental issues and interacting with both people who "generally want to [do] the right thing... Some people don't really seem to care. Varies, I guess." Roland indicated that different engineering jobs and disciplines had very different situations that would be relevant. He thought that hearing more engineers talk about real-world ethical situations they encountered could have been helpful. He indicated that one course allowed students some control in which topics they discussed, and that many based their choices on internship experiences. In comparison to the alumni from the religiously-affiliated institutions, Roland's feelings about his preparation for ethical issues in practice seemed more equivocal.

The six alumni from the control institution tended to discuss the shortcomings of their ethics education to an even greater extent than Roland. The three with longer engineering work experience (7-20 years, Brad, Melissa, and Shane) described feeling somewhat unprepared for a variety of ethical situations on the job. For example, Brad stated:

I think that [ethics] was something that wasn't a broad... focus of a lot of time in the undergraduate curriculum. And as a result, I think that there was a little bit of an under preparedness going into the industry as far as how to navigate certain things... what's actually the ethical dilemmas that you might encounter are and how to be prepared for them... we could have used more focus on preparing students for the ethical and societal impact implications within practice.

Shane didn't recall anything specific about ethics education in his undergraduate courses: "I can't think of necessarily anything specific. I recall some level of ethics discussion, I believe it was in my introduction course, and I remember some in the early engineering [courses]. But the specifics, I couldn't tell you." Recall bias may be impactful in these cases, given the longer amount of time that had elapsed since these engineers had taken courses in college. However, it is also probable that ethics integration increased in civil/environmental engineering at the institution over the last decade due to ABET and other faculty motivations.

The more recent graduates from the program (6 to 18 months) were less critical of their ethics education. They generally recalled ethics briefly integrated into about three courses (first year, senior capstone, and one additional example). Anne's experience seemed typical,

I think what I took away from those courses was very much the fact that as an engineer... you're held to a certain accountability that you really need to uphold in order to be an 
effective professional. And I think also just like keeping mindful of the fact that a lot of our designs are things that ... have some sort of societal impact is very important. ... And so I think that was really helpful, especially in my work now.

The basic expectation and reason for ethical behavior were clear but without focused examples. These younger engineers did not describe significant experiences with ethical situations in their work, although this may be somewhat related to having less sophisticated skills for identifying ethical issues. The alumni from the control institution all advocated for greater engineering ethics education, but they believed the best strategy would be through integration into existing engineering courses (not believing there was space to add an additional required course).

Some of the interviews noted that ethics training continued on-the-job, and that ethics issues evolved over time as one changed positions (e.g., moving into management roles, cited by Brad and Melissa) or industry standards changed (e.g., diversity and inclusion issues, cited by Brad, Kathy, Shane). An alumnus from I1 stated in the final open-ended question on the survey, "Most of what I needed to know when starting a job after college was part of the training at my company. Some was new material, some was repeat of what was learned in college. Most companies have mandatory ethics training; my company has required training every quarter." This job training seems important as another survey respondent (from I7) noted, "Some things cannot be taught in a classroom. I'm very happy with my education." So while education may not be able to teach about every situation, a solid grounding in ethical reasoning and decision making along with developing an attitude that commits to ethical behavior is an achievable goal.

\section{Limitations}

Limitations in the work include the use of a survey instrument that has not been rigorously evaluated for evidence of validity and reliability. In addition, the responses represent a fairly small sample that crosses multiple disciplines. It cannot be established that the responses are representative of the engineering alumni from these 'exemplar' courses; for example, the sample may be biased to individuals who enjoyed the course and/or instructor, or feel that engineering ethics is an important part of their work. More broadly, the alumni respondents should not be generalized to all working engineers. The alumni who responded to the survey represented a variety of employment sectors and number of years of employment. In some cases, such as alumni from I2, the content of the senior-level exemplar course that integrated professional issues and ethics changed a lot over the three years as the instructor modified the course. In other courses, the content did not change significantly in the exemplar course, but other courses and requirements in the curriculum as a whole may have changed. Further, the ethical issues encountered likely evolve over time as an engineer moves from a junior level to more senior roles. The interview findings more clearly indicate that the diverse experiences of engineers that occur after graduation may impact perceptions. The timing of the study means that the majority of the engineering alumni would have experienced education that complied with the ABET 'A to $\mathrm{K}$ ' criteria rather than the current ABET outcomes where environmental and societal impacts are integrated into the ethics-related outcome. Given the limitations in the study, the results should be considered exploratory rather than conclusive, with a goal to motivate and inform future, larger studies. 


\section{Summary}

The results provide insights into how educational practices are influential in terms of the knowledge, attitudes, and behaviors of working engineers with respect to ethics and broader impacts. The alumni perspectives reflect the diversity of the approaches tried for engineering ethics education, with positive attitudes toward ethics integrated into first-year courses, senior capstone design, and ethics-focused courses, as well as teaching methods including project based service-learning, case studies, and discussions. Some alumni appreciated a theoretical basis to ethics broadly, with philosophical grounding. Others desired more practical examples from workplace settings. Clearly there is not a single approach that is best for all, given the different interests and maturity of students and differing downstream career paths. A broader commitment at the program and/or institution levels seems to be recognized by alumni. Practically, professors and programs are encouraged to include alumni perspectives in assessing their ethics teaching practices. While alumni cannot give informed opinions on what would be better, they can provide valuable insights into what is working best. In addition, their stories may help faculty to better appreciate contemporary ethical challenges faced by working engineers. These narratives can serve as authentic examples for students, which may generate rich discussions and reflections that enhance students' ethical reasoning skills.

\section{Acknowledgements}

This material is based on work supported by the National Science Foundation under Grant $\# 1540348$, \#1540341, \#1540308, and \#1755390. Any opinions, findings, and conclusions or recommendations expressed in this material are those of the authors and do not necessarily reflect the views of the National Science Foundation. The authors also thank Nathan Canney, Ph.D., P.E., who collaborated on the broader project.

\section{References}

[1] C.E. Harris, M.S. Pritchard, R.W. James, E.E. Englehardt, M.J. Rabins. 2019. Engineering Ethics: Concepts and Cases. $6^{\text {th }}$ Edition. Cengage Learning, Boston MA.

[2] G.D. Catalano. 2011. Tragedy in the Gulf: A Call for a New Engineering Ethic. Morgan \& Claypool. DOI 10.2200/S00322ED1V01Y201012ETS015

[3] Y. Lambrinidou. 2018. "When technical experts set out to 'do good': deficit-based constructions of 'the public' and the moral imperative to new visions of engagement," Michigan Journal of Sustainability, 6 (1), DOI: http://dx.doi.org/10.3998/mjs.12333712.0006.102

[4] ASEE. 2019. Distinguished lecture: Community engagement ethics - first steps in a conversation with affected communities. Speakers: S. Brown, E.Y. Lewis, R. Miranda, A.P. Naquin, L. Young-Green. Moderator: D. Karwat. American Society for Engineering Education Annual Conference \& Exposition. Tampa FL, June 16-19. https://www.asee.org/public/conferences/140/registration/view session?session $\mathrm{id}=10494$

[5] J.A. Leydens and J.C. Lucena. 2018. Engineering Justice: Transforming Engineering Education and Practice. John Wiley \& Sons Inc., Hoboken NJ.

[6] Texas Board of Professional Engineers. 2017. Board Meeting Disciplinary \& Administrative Actions. Nov. 16. https://pels.texas.gov/da/da11162017.html Accessed Nov. 3, 2020.

[7] NCEES. 2020. FE Reference Handbook 10.0.1. ISBN 978-1-947801-11-0

[8] Texas Board of Professional engineers. N.D. Texas Engineering Professional Conduct and Ethics Examination. https://pels.texas.gov/downloads/ethics_exam.pdf 
[9] A.R. Bielefeldt 2020. Ethics experiences and educational recommendations for working engineers. Environmental Engineering Graduate Seminar, University of Colorado Boulder, Oct. 2. (unpublished)

[10] B.E. Barry and J.R. Herkert. 2014. "Chapter 33: Engineering Ethics," in Cambridge Handbook of Engineering Education Research. Ed. A. Johri and B.M. Olds, Cambridge University Press. pp. 673692.

[11] ABET Engineering Accreditation Commission. 2017. Criteria for Accrediting Engineering Programs, Effective for Reviews During the 2018-2019 Accreditation Cycle. ABET, Baltimore MD. Available at: https://www.abet.org/accreditation/accreditation-criteria/accreditation-changes/ Accessed May 30, 2021.

[12] J. Beever and A.O. Brightman. 2016. "Reflexive principlism as an effective approach for developing ethical reasoning in engineering," Sci Eng Ethics, 22, 275-291.

[13] Q. Zhu and B.K. Jesiek. 2017. "A pragmatic approach to ethical decision-making in engineering practice: Characteristics, evaluation, critiera, and implications for instruction and assessment," Sci Eng Ethics, 23, 663-679. DOI 10.1007/s11948-016-9826-6

[14] L. Shuman, M. Besterfield-Sacre, M. Sindelar, H. Wolfe, R. Miller, B. Olds, C. Mitcham. 2003. The Pittsburgh-Mines (P-M) Engineering Ethics Assessment Rubric. NSF DUE 01 27394. Available at: https://www.engineering.pitt.edu/uploadedFiles/_Content/Sub_Sites/Centers/EERC/_Documents/Ref erence Materials/Pittsburgh-Mines\%20Engineering\%20Ethics\%20Assessment\%20Rubric.pdf Accessed May 30, 2021.

[15] D. Bairaktarova and A. Woodcock. 2017. "Engineering students' ethical awareness and behavior: A new motivational model," Sci Eng Ethics. 23, 1129-1157.

[16] T.S. Harding, M.J. Mayhew, C.J. Finelli, D.D. Carpenter. 2007. "The theory of planned behavior as a model of acadmic dishonesty in engineering and humanities undergraduates," Ethics \& Behavior, 17 (3), 255-279. DOI: 10.1080/10508420701519239.

[17] S.D. Gelfand. 2016. "Using insights from applied moral psychology to promote ethical behavior among engineering students and professional engineers," Sci Eng Ethics, 22, 1513-1534.

[18] T.S. Harding, C. Finelli, and D. Carpenter. 2006. "Cheating in college and its influence on ethical behavior in professional engineering practice," Proc. American Society for Engineering Education (ASEE) Annual Conference \& Exposition. 13 pp. DOI 10.18260/1-2-357. https://peer.asee.org/357

[19] A.R. Bielefeldt, M. Polmear, D. Knight, C. Swan, N. Canney. 2017. "Intersections between engineering ethics and diversity issues in engineering education," J Prof Issues Eng Edu Pract. 144 (2), 11 pp. DOI: 10.1061/(ASCE)EI.1943-5541.0000360.

[20] A.R. Bielefeldt, M. Polmear, N. Canney, C. Swan, D. Knight. 2019. "Institutional variations in ethics and societal impacts education: Practices and sufficiency perceptions among engineering educators," Proc. American Society for Engineering Education (ASEE) Annual Conference \& Exposition. 17 pp. DOI: 10.18260/1-2-32972. https://peer.asee.org/32972.

[21] J.L. Hess and G. Fore. 2018. "A systematic literature review of U.S. engineering ethics interventions," Sci Eng Ethics, 24, 551-583.

[22] A.R. Bielefeldt, M. Polmear, D. Knight, N. Canney, and C. Swan. 2019. "Disciplinary variations in ethics and societal impact topics taught in courses for engineering students," J. Prof. Issues Eng Edu Pract. 145 (4). DOI: 10.1061/(ASCE)EI.1943-5541.0000415.

[23] R. Stevens, A. Johri, and K. O’Connor. 2012. Professional Engineering Work. In: Cambridge Handbook of Engineering Education Research, Ed. A. Johri, B.M. Olds. Cambridge University Press. Pp. 119-138.

[24] E.A. Cech. 2014. "Culture of disengagement in engineering education?" Science, Technology, \& Human Values. 39(1), 42-72. DOI: 10.1177/0162243913504305.

[25] P.A. Vesilind and A.S. Gunn 1998. Engineering, ethics, and the environment. Cambridge University Press.

[26] T. Nathans-Kelly, S. Courter, K. Anderson, C. Nicometo, T. McGlamery. 2010. "In-situ ethics: The ethical sensibility that engineers bring to their work," Proc. American Society for Engineering 
Education (ASEE) Annual Conference \& Exposition. Paper AC 2010-1283. 14 pp. DOI: 10.18260/12-16437. https://peer.asee.org/16437.

[27] A.R. Bielefeldt and N.E. Canney 2016. "Perspectives of engineers on ethical dilemmas in the workplace," Proc. American Society for Engineering Education (ASEE) Annual Conference \& Exposition. Paper ID \#15373. 18 pp. DOI: 10.18260/p.25892.

[28] G. Nudelman and J. English. 2019. "Ethical dilemmas experienced by engineering students during their vacation work," J Professional Issues in Engineering Education and Practice. 145(2). 8 pp. DOI: 10.1061/(ASCE)EI.1943-5541.0000406.

[29] C.G. Nicometo, T. Nathans-Kelly, B. Skarzynski. 2014. "Mind the gap: Using lessons learned from practicing engineers to teach engineering ethics to undergraduates," Proc. IEEE International Symposium on Ethics in Science, Technology and Engineering. 7 pp. DOI: 10.1109/ETHICS.2014.6893430.

[30] C.J. Finelli, M.A. Holsapple, E. Ra, R.M. Bielby, B.A. Burt, D.D. Carpenter, T.S. Harding, J.A. Sutkus. 2012. "An assessment of engineering students' curricular and co-curricular experiences and their ethical development," Journal of Engineering Education, 101 (3), 469-494.

[31] J.C. Weidman. 2006. "Socialization of students in higher education: Organizational perspectives." In The SAGE Handbook for Research in Education: Engaging ideas and enriching inquiry (pp. 253262). Sage, Beverley Hills.

[32] NAE - National Academy of Engineering. (2018). Understanding the Educational and Career Pathways of Engineers. Washington DC: The National Academies Press. Available at: https://doi.org/10.17226/25284.

[33] M. Polmear, A.R. Bielefeldt, D. Knight, C. Swan, N. Canney. 2020. "Exploratory investigation of personal influences on educators' engagement in engineering ethics and societal impacts instruction," Sci Eng Ethics, 26, 3143-3165. DOI: 10.1007/s11948-020-00261-x.

[34] A.R. Bielefeldt, M. Polmear, D. Knight, N. Canney, C. Swan. 2018. "Effective ethics education: Examining differing faculty perspectives," Proc. American Society for Engineering Education (ASEE) Annual Conference \& Exposition. 20 pp. DOI: 10.18260/1-2--30355. https://peer.asee.org/30355.

[35] G. Norman. 2010. "Likert scales, levels of measurement and the "laws" of statistics," Adv in Health Sci Educ, 15, 625-632.

[36] W. S. Sarle. 1995. "Measurement theory: Frequently asked questions," Disseminations Int. Stat. Appl. Inst., 1(4), 61-66.

[37] B.O. Baker, C.D. Hardyck, and L.F. Petrinovich. 1966. "Weak measurements versus strong statistics: An empirical critique of S. S. Stevens' proscriptions on statistics," Educ. Psychol. Meas., 26(2), 291309.

[38] A.R. Bielefeldt, J.W. Lewis, M. Polmear, D. Knight, C. Swan. 2021. "Engineering alumni rate the impact of extracurricular activities on their ethical development," Proc. American Society for Engineering Education (ASEE) Annual Conference \& Exposition. 18 pp.

[39] M. Polmear, A. Bielefeldt, D. Knight, N. Canney, C. Swan. 2019. "Hidden curriculum perspective on the importance of ethics and societal impacts in engineering education," Proc. American Society for Engineering Education (ASEE) Annual Conference \& Exposition. 20 pp. DOI: 10.18260/1-232887. https://peer.asee.org/32887. 


\section{Appendix - Alumni Survey Instrument}

Informed consent information: yes, I consent; no, I do not agree to participate

1. To what extent do you remember learning about ethics and/or societal impact issues in Professor X's Y course? [multiple choice] 1 - Do not remember at all; 2; 3 - Remember moderately well; 4; 5 - Remember very well

2. Was there anything about the course that was impactful to your views on ethics and/or societal impacts? If so, please explain. [open text response]

3. Was learning about ethics and/or societal impacts in this course helpful to you in your work? If so, please explain. [open text response]

4. List the ethical issues that you think are relevant to practicing engineers or computer scientists.

5. Are you currently working as an engineer or computer scientist? Yes; No [skip to Q5b]

$5 b$. After graduating from college, did you ever work as an engineer or computer scientist? Yes; No [skip to Q

6 . How [do/did] you view your role in society as an engineer or computer scientist?

7. How important do you believe ethical issues are to engineering and computer science? [multiple choice] $1=$ Very unimportant, 2, 3, 4, 5, 6, 7, 8, 9, $10=$ Very important

8. How important do you believe the consideration of societal issues is to engineering and computer science? $1=$ Very unimportant, 2, 3, 4, 5, 6, 7, 8, 9, $10=$ Very important

9. What courses in college (undergraduate or graduate), if any, impacted your ethical knowledge, reasoning, or behavior? If any, how were they impactful? [open text response]

10. What courses in college (undergraduate or graduate), if any, impacted your understanding of the role of engineering and/or computing in society? If any, how were they impactful? [open text response]

11 To what extent did co-curricular activities and/or informal learning experiences during college impact you ethical knowledge, reasoning or behavior? \{multi-selection\}

Activities: Internship or co-op, research, Professional society, Engineering service group, Honor society, Design group, Volunteer activity, Fraternity / sorority, Sports, Others (fill in)

Extent: Was not involved during college, Was involved but no impact, Small impact, Moderate impact, Large impact

12 To what level do you believe you were adequately prepared through your education to face ethical issues in your work? [multiple choice] $\quad 1=$ Fully unprepared, $2,3,4,5,6,7,8,9,10=$ Fully prepared

13. To what level do you believe you were adequately prepared through your education to consider societal issues in your work? [multiple choice] 1 = Fully unprepared, 2, 3, 4, 5, 6, 7, 8, 9, $10=$ Fully prepared

14. In your work as an engineer or computer scientist, rate how often you have encountered issues related to the topics below in your work: Frequency: never, rarely, monthly, weekly, daily

Topics: bioethics, bribes, confidential/proprietary information, conflict of interest, diversity, engineering and poverty, engineering decisions in the face of uncertainty, environmental protection issues, ethics in design, intellectual property, legal compliance issues, nanotechnology ethics, privacy and civil liberties, responsible conduct of research, risk and liability, safety, social justice, sustainability and/or sustainable development, war/military applications, peacemaking, whistle blowing, other

15. Optional: Share any comments about your education or work environmental related to ethics and the societal impacts of engineering/technology. [open text response]

16 Optional: If you would be willing to participate in an interview about how the instruction you received on ethics/societal impact as a student impacted you after graduation, enter your preferred contact email:

17. Demographics

In what year did your take Professor XXX's YYY course

In what year did you earn your Bachelor's degree

What was your major for your Bachelor's degree

Did you earn graduate degrees? If yes, discipline, year of highest degree

Types of engineering and/or computing job you have worked at (check all that apply)

Gender, Race/ethnicity, Did you grow up primarily in the USA

Email to receive \$10 Amazon gift card 